\title{
Implications of the Central America- Dominican Republic-Free Trade Agreement for the nutrition transition in Central America
}

\author{
Corinna Hawkes ${ }^{1}$ and Anne Marie Thow ${ }^{2}$
}

Suggested citation Hawkes C, Thow AM. Implications of the Central America-Dominican Republic-Free Trade Agreement for the nutrition transition in Central America. Rev Panam Salud Publica. 2008;24(5):345-360.

ABSTRACT Objectives. To identify potential impacts of the Central America-Dominican Republic-Free Trade Agreement (CAFTA-DR) on food consumption patterns associated with the nutrition transition, obesity, and diet-related chronic diseases.

Methods. Examination of CAFTA-DR agreement to identify measures that have the potential to affect food availability and retail prices.

Results. CAFTA-DR includes agreements on tariffs, tariff-rate quotas (TRQs), and sanitary and phytosanitary regulations with direct implications for the availability and prices of various foods. Agreements on investment, services, and intellectual property rights (IPR) are also relevant because they create a business climate more conducive to long-term investment by the transnational food industry. Trade liberalization under CAFTA-DR is likely to increase availability and lower relative prices of two food groups associated with the nutrition transition: meat and processed foods. These outcomes are expected to occur as the direct result of increased imports from the United States and increased production by U.S. companies based in Central America, and the indirect result of increased domestic meat production (due to increased availability of cheaper animal feed) and increased production of processed foods by domestic companies (due to a more competitive market environment).

Conclusions. CAFTA-DR is likely to further the nutrition transition in Central America by increasing the consumption of meat; highly processed foods; and new, non-traditional foods. The public health community should be more aware of the implications of trade agreements for dietary health. Governments and related stakeholders should assess the coherence between changes fostered by specific trade agreements with national policies on diet and nutrition.

Key words Economic development, obesity, chronic disease, nutrition disorders, economics, Dominican Republic, Central America.

At the time of the study: Research Fellow, International Food Policy Research Institute, Washington, D.C., United States of America; present affiliation: Freelance Consultant and Visiting Research Fellow, Centre for Food Policy, City University, London, United Kingdom. Send correspondence and reprint requests to: Corinna Hawkes, Freelance Consultant, Le Pouget, 43380 Lavoute-Chilhac, France; e-mail: corinnahawkes@aliceadsl.fr

2 At the time of the study: Intern, International Food Policy Research Institute, Washington, D.C., United States of America; present affiliation: Australian Health Policy Institute, University of Sydney, New South Wales, Australia.
The "nutrition transition" refers to the trend in developing countries toward declining consumption of staples and increasing consumption of energy-dense, processed, and animalsource foods, which tend to be high in fats and/or sweeteners (1). Throughout the developing world, the nutrition transition is associated with the development of overweight/obesity and diet-related chronic diseases such as heart disease, diabetes, and some cancers. Chronic diseases are estimated by the World Health Organization (WHO) to be the leading cause of death worldwide.

Though measurements of dietary changes are sparse, available evidence suggests that Central America is undergoing the nutrition transition: Data 
from the Food and Agricultural Organization (FAO) shows that since 1990 the proportion of calories from protein and fat has increased (2). This is largely attributed to meat consumption, which increased from 32.6 to 49.9 kg/capita/year between 1989-1991 and 2001-2003, mainly due to chicken consumption, which rose from 9.5 to $22.0 \mathrm{~kg} /$ capita/year (2). At the same time, the proportion of energy obtained from cereals declined, while that from fruits and vegetables remained stable. In one of the few studies measuring dietary patterns, Stein et al. concluded that inhabitants of Guatemalan villages demonstrated dietary habits reflecting early stages of the nutrition transition, with high carbohydrate and moderate fat intakes, including some penetration of "transitional" foods such as hamburgers, ice cream, confectionery, chocolates, sausages (e.g., hot dogs), potato chips, and other snacks (3).

These changes are concurrent with increasing obesity and heart disease in the region. Data from nationally representative surveys show that overweight/obesity is increasing at a rate of around 1.5-2.0\% annually. ${ }^{3} \mathrm{Na}$ tional prevalence of overweight and obesity in women between 15 and 49 years ranges from $42 \%$ (in Honduras) to 54\% (in El Salvador). Obesity in infants and preschool children has increased markedly in all countries since the 1980s.

The nutrition transition has many causes, ranging from changes in income, employment, and rate of urbanization, to more distal causes related to economics, culture, and technology (1). A major economic cause of the nutrition transition is global market integration (often termed "globalization") (4-7). One of the main processes of globalization is trade liberalizationthe complete or partial elimination of government policies or subsidies that adversely affect trade. Trade liberalization can affect food availability and retail prices (Table 1) by encouraging

\footnotetext{
Ramírez-Zea M. Trends in obesity and chronic diseases in Meso-America [seminar]. At: Program in International and Community Nutrition (PIN), University of California-Davis, 29 March 2006.
}

TABLE 1. Some potential effects of trade liberalization on food availability and retail prices

\begin{tabular}{|c|c|c|}
\hline \multirow[b]{2}{*}{$\begin{array}{c}\text { Area of } \\
\text { potential effect }\end{array}$} & \multicolumn{2}{|c|}{ Trade liberalization measure } \\
\hline & $\begin{array}{c}\text { Reducing } \\
\text { import barriers on foods }\end{array}$ & $\begin{array}{c}\text { Reducing } \\
\text { investment barriers }\end{array}$ \\
\hline Food availability & $\begin{array}{l}\text { Can lead to increased imports, and } \\
\text { therefore availability, although this } \\
\text { depends on whether imports replace } \\
\text { domestic production. If domestic } \\
\text { production declines at the same time } \\
\text { as higher imports, the net effect of } \\
\text { food imports on availability could be } \\
\text { zero or even negative. The effect on } \\
\text { availability also depends on the } \\
\text { amount of exports. }\end{array}$ & $\begin{array}{l}\text { Can stimulate incentives for domestic } \\
\text { food processing by foreign-owned } \\
\text { companies and, through competition, } \\
\text { domestic enterprises. The net effect on } \\
\text { availability depends on whether foreign } \\
\text { direct investment (FDI) replaces or } \\
\text { supplements trade in processed foods. } \\
\text { Reducing investment barriers can also } \\
\text { promote the growth of transnational } \\
\text { supermarket, food service outlets, and } \\
\text { advertising companies through which } \\
\text { processed foods can be sold and } \\
\text { promoted. }\end{array}$ \\
\hline Food retail prices & $\begin{array}{l}\text { Can have the effect of lowering retail } \\
\text { food prices, if prices of imported foods } \\
\text { are lower. The actual effect on retail } \\
\text { prices depends on the price } \\
\text { transmission between international } \\
\text { and domestic prices and the effect } \\
\text { of trade liberalization on domestic } \\
\text { production. }\end{array}$ & $\begin{array}{l}\text { Can have the effect of reducing retail } \\
\text { food prices, as transnational food } \\
\text { companies (TFCs) often buy agricul- } \\
\text { tural commodities at lower prices and } \\
\text { produce at economies of scale relative } \\
\text { to small-scale companies. On the other } \\
\text { hand, TFCs' control of the marketplace } \\
\text { allows them to accrue the benefits of } \\
\text { lower agricultural prices for their own } \\
\text { profits and, in the absence of } \\
\text { increased competition, charge higher } \\
\text { retail prices for their foods. }\end{array}$ \\
\hline
\end{tabular}

Source: Author's compilation.

greater imports of foods produced at lower prices; facilitating greater foreign direct investment (FDI) in food production, processing, retailing, and advertising; and stimulating the growth of transnational food companies (TFCs) $(5,8)$. These changes in food availability and retail prices can, in turn, influence food consumption patterns.

Trade liberalization has been ongoing in Central America since the 1980s, when the U.S.-sponsored Caribbean Basin Initiative (1983) granted tariff and trade benefits to Central American and Caribbean countries exporting to the United States. Since then, Central American countries have steadily opened up their borders to increased trade with the United States and other countries, culminating in 2006 with the Central America-Dominican RepublicFree Trade Agreement (CAFTA-DR), the most significant trade agreement ever signed in the Central American region (9). Like the North American Free Trade Agreement (NAFTA) signed in 1994 by the United States, Canada, and
Mexico, CAFTA-DR aims to facilitate the exchange of goods, investments, and services between the United States and participating countries (in this case, Costa Rica, El Salvador, Guatemala, Honduras, Nicaragua, and the Dominican Republic). CAFTA-DR was signed by treaty participants in 2004 and had an original target date for implementation of 1 January 2006 (10). Actual implementation of CAFTA-DR has occurred on a rolling basis. In the United States, the legislation was ratified in 2005. El Salvador ratified the agreement on 1 March 2006, followed by Honduras and Nicaragua on 1 April 2006, Guatemala on 1 July 2006, and the Dominican Republic on 1 March 2007. After much debate, a referendum approved the agreement in Costa Rica on 7 October 2007.

This study examines the implications of CAFTA-DR for food consumption, within the context of the nutrition transition, in the Central American signatory countries (i.e., it does not analyze potential effects in the Dominican Re- 
public). It aims to identify if and how CAFTA-DR may affect the consumption of foods associated with the nutrition transition, obesity, and diet-related chronic diseases. The analysis considers potential changes in imports and investment from the United States into the five Central American countries (i.e., it does not cover potential changes in imports and investment from Central America into the United States).

\section{MATERIALS AND METHODS}

The potential impacts of CAFTA-DR on food availability and retail prices were identified through a review of the policies set out in the CAFTA-DR agreements, a process that drew significantly on existing reviews of the agreements. Two important sources were the World Bank report DRCAFTA; challenges and opportunities for Latin America (2005) (9) and the 2006 report by Morly, Trade liberalization under CAFTA (11). The specific foods most likely to be affected by CAFTADR were identified through a detailed examination of the tariff schedules and their annexes. These schedules provided information on how tariffs will change, at a very detailed level, using the International Harmonized Commodity Coding and Classification System (HS). Each food is identifiable through its HS code. This information was then compiled to determine if CAFTA-DR has implications for food consumption patterns and, subsequently, to develop hypotheses on its potential implications for the nutrition transition.

\section{RESULTS}

\section{CAFTA-DR policy measures with implications for food consumption}

CAFTA-DR covers the trade of goods, investments and services, and other measures designed to instill confidence in private companies to do business in the region. The agreement comprises a total of 22 chapters aimed at facilitating trade or otherwise pertaining to the

TABLE 2. Categorization and definition of policy measures in Central America-Dominican Republic-Free Trade Agreement (CAFTA-DR) directly affecting trade of agricultural goods

\section{Reduction of tariff barriers \\ Tariff reductions \\ Reduction of non-tariff barriers $^{\mathrm{a}}$ \\ Increases of TRQs}

\section{Measures implemented to protect domestic agriculture Exemption of "sensitive products"}

Adherence to WTO SPS Agreement

Use agricultura safeguards

Anti-dumping measures

A tariff is a tax on an import (often called a "customs duty") paid by the exporter. A tariff may be either a fixed charge per unit of product imported (specific tariff) or a fixed percentage of value (ad valorem tariff). A bound tariff rate is the maximum tariff a country is permitted to set under a trade agreement. High tariffs inhibit trade because they create a disincentive for countries to export their goods. Reducing tariffs therefore facilitates trade.

A quota is the maximum quantity or value of a commodity allowed to enter a country during a specified period. A tariff-rate quota (TRQ) is a quota on an imported good above which a higher tariff rate is applied. A lower tariff rate applies to any imports below the quota amount. Thus increasing the TRQ increases the amount of the good that can be imported at the lower tariff rate, thereby facilitating trade.

Sanitary and phytosanitary (SPS) measures are national measures that aim to reduce hazards to animal, plant, and human health, including food safety regulations. The 1995 World Trade Organization (WTO) Agreement on the Application of Sanitary and Phytosanitary Measures (SPS) sets out rules concerning these measures. The SPS Agreement recognizes that countries have a legitimate need to protect human health from unsafe food, but upholds the principle that these measures should distort trade as little as possible, thereby facilitating trade.

A sensitive product is a product exempted from the measures implemented to facilitate trade for other products. Exempting sensitive products from greater trade openness is a measure used to protect producers of products who are likely to be disproportionately affected by liberalization (on the basis that it may undermine their livelihoods).

Safeguards are provisions permitted under WTO regulations under which imports beyond the safeguard level can be temporarily restricted if the affected industry can show it will suffer serious injury from the level of imports beyond the safeguard level. In most cases, the safeguard level tariffs in CAFTA-DR fall over time.

Measures permitted under WTO regulations that allow countries to halt "dumping" (the sale of products on the world market below the cost of production in order to dispose of surpluses or gain access to a market). Dumping is generally recognized as an unfair trade practice because it can disrupt markets and injure producers of competitive products in an importing country.

Sources: $(14,58-60)$

a Non-tariff barriers are regulations used by governments to restrict imports from and exports to other countries, including quotas, embargoes, and technical barriers (e.g., packaging, marking, and labeling standards and testing and certification procedures)

trade of goods, investment and services, intellectual property rights (IPR), sanitary and phytosanitary measures, labor, and the environment. Some measures include references to public health.

Trade of agricultural goods. The CAFTA-DR measures with the most direct implications for food are those related to the trade of agricultural goods. Table 2 defines, categorizes, and explains these measures, which can be divided into three categories: reduction of tariff barriers, reduction of non-tariff barriers, and protective measures.

Prior to CAFTA-DR, average applied tariff rates for various agricultural commodities ranged from $0.7-39.7 \%$, while the total range was $0-151 \%$ (12-13). Over the long-term, CAFTA-DR eliminates tariffs on these 
products (with a few exceptions). With regard to exports from the Central American countries into the United States, CAFTA-DR makes permanent the reductions agreed upon under the 1983 Caribbean Basin Initiative, which was due to expire in 2008. Under the Initiative, $80 \%$ of the region's exports already enter the United States tarifffree. Therefore, in regard to tariffs on exports from Central America into the United States, which were already low or zero when CAFTA-DR was implemented, the treaty is expected to have a negligible effect, although some products will now enjoy easier access (11).

The main changes thus arise as a result of reductions in tariffs for exports from the United States into Central America. Many tariffs will be completely removed upon implementation, while others will be phased out gradually over 5-18 years. Each tradable good falls under one of 13 tariff reduction categories $(\mathrm{A}-\mathrm{Q})$ based on various characteristics (Table 3 ), with some products grouped in the same categories across different countries. CAFTA-DR also reduces tariffs on equipment for food processing, storage, and packaging. As a protective measure, a small number of "sensitive products" (products exempted from trade liberalization measures) (Table 2) will be exempted from zero-tariff status, even over the long term. ${ }^{4}$ The CAFTA-DR agreement also contains agricultural safeguards and antidumping measures to protect domestic agriculture (Table 2).

Non-tariff barriers (Table 2) will also decline under the agreement. For example, tariff-rate quotas (TRQs) will be increased for a subset of food products. These foods tend to be "sensitive products" with the highest average tariff levels and are imported into the countries at relatively high volumes) (11). Most TRQs for these products will grow gradually at annual rates of 2-5\% over the next decade. Because the high tariffs on these products affect only out-of-quota amounts (versus in-TRQ

\footnotetext{
4 Sugar for entry into the United States; white corn for entry into El Salvador, Guatemala, Honduras, and Nicaragua; and potatoes and onions for entry into Costa Rica.
}

amounts), the increasing size of the TRQs will boost imports of these products faster than the rate of increase implied in the tariff reduction schedule.

CAFTA-DR will also facilitate trade by promoting the harmonization of U.S. and Central American signatory country sanitary and phytosanitary rules, particularly food inspection procedures for meat and poultry (14-15).

Trade in investment. CAFTA-DR consolidates existing foreign investment laws and bilateral treaties by granting U.S. investors the same rights as domestic investors (16-20). For example, the investment provisions in CAFTADR prohibit governments from imposing performance requirements (such as minimum usage of local inputs) on foreign investment (9). Unlike the measures pertaining to the trade of goods, the treaty's investment measures do not specifically apply to food. Nonetheless, by facilitating foreign investment in food processing, retailing, and advertising, they have potentially important implications for food (8).

Trade in services. CAFTA-DR commitments in the service sector (e.g., finance and telecommunications) lock in existing legislation granting U.S. firms operating in Central America the same rights as domestic firms when applying for contracts and providing services (9). These service measures thus affect food indirectly by regulating the provision of services that facilitate trade and investment by TFCs operating in the United States. For example, because food is a heavily advertised product, CAFTA-DR agreements on advertising will indirectly affect the consumption of food products. Under the agreement, Nicaragua, Honduras, and Guatemala will open their advertising markets to the United States. El Salvador maintains a local content quota for commercials, but does not apply this requirement to foreign-made commercials for imported U.S. goods and services. CAFTA-DR thus goes beyond the World Trade Organization (WTO) General Agreement on Trade in Services (GATS), in which none of the five Central American sig- natories of CAFTA-DR made commitments regarding advertising (21).

Intellectual property rights. CAFTADR grants greater IPR to private enterprises (9) by:

- Obliging countries to ratify international agreements dealing with trademarks and patents;

- Establishing minimum protection standards for brands and other patent-related standards;

- Introducing new procedures and resources for the enforcement of IPR.

These agreements are relevant to the transnational food industry, given its extensive use of brand-name products.

Measures relevant to public health Only a few clauses in the CAFTA-DR agreement refer specifically to public health, and diet and nutrition are not mentioned at all. Protections to promote public health, which several U.S. civil society organizations have criticized for being too weak (22-24), are summarized below. Chapter 6 (Sanitary and phyto-sanitary measures) is directly relevant to food.

- Sanitary and phyto-sanitary measures (chapter 6): Countries must apply the science-based disciplines of the WTO Agreement on Sanitary and Phytosanitary Measures (SPS) (Table 2), which includes the statement "the objectives of this Chapter are to protect human, animal, or plant life or health" (14).

- Understanding regarding certain public health measures (section labeled "IP understanding on public health"): This part of the agreement states that the obligations of the agreement on IPR should not affect any country's ability to "take necessary measures to protect public health by promoting access to medicines for all, in particular concerning cases such as HIV/AIDS, tuberculosis, malaria, and other epidemics, as well as circumstances of extreme urgency or emergency" (25).

- Labor and Environment (chapters 16-17): CAFTA-DR commits all 
TABLE 3. Tariff categories under Central America-Dominican Republic-Free Trade Agreement (CAFTA-DR)

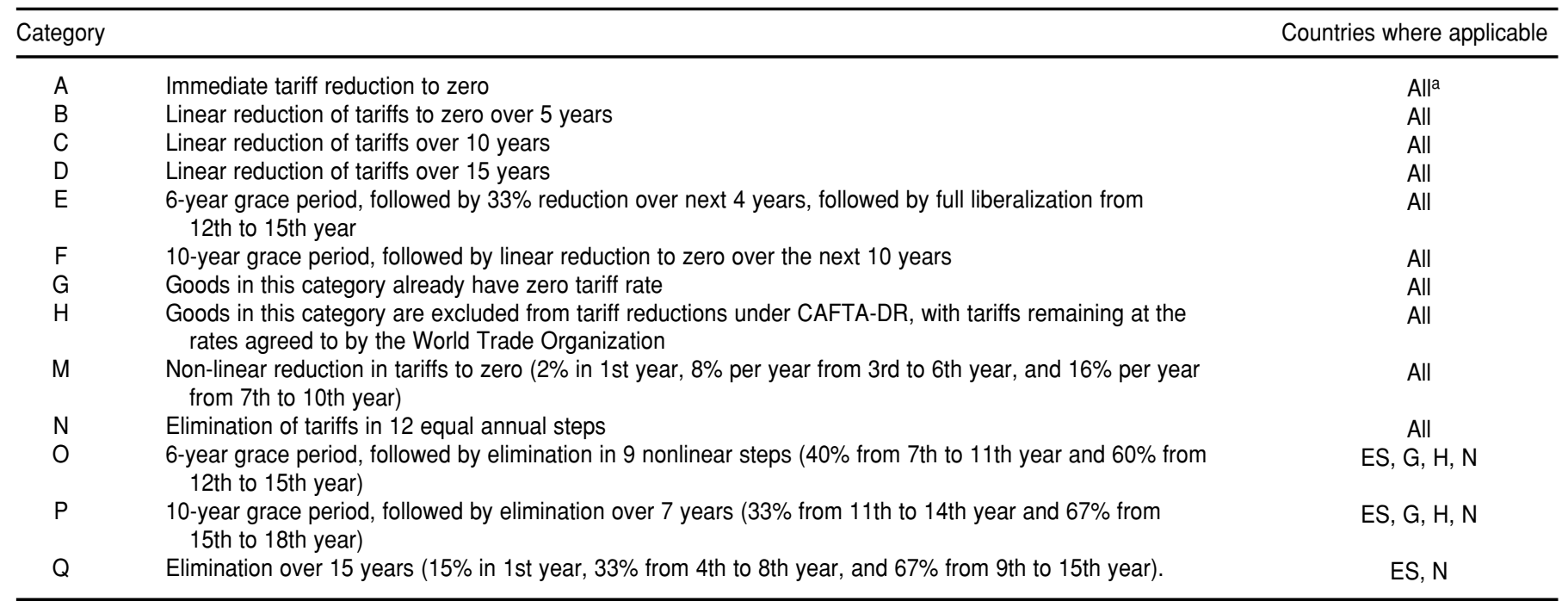

Source: (11).

${ }^{a}$ All Central American signatory countries (Costa Rica, CR; El Salvador, ES; Guatemala, G; Honduras, H; and Nicaragua, N)

countries to enforce domestic labor and environmental laws and regulations, which includes laws on occupational and environmental health (26-27).

\section{Implications of CAFTA-DR for food availability and prices}

In 2004, the United States exported almost US $\$ 16$ billion in goods to Central American countries and the Dominican Republic, including US $\$ 1.8$ billion of agricultural products (21). Some of these agricultural exports form a significant percentage of total product availability in the region (relative to domestic production and/or imports from other countries).

International financial institutions, the U.S. Department of Agriculture (USDA), the Office of the U.S. Trade Representative (USTR), and farm business groups predict that, for most products, CAFTA-DR measures will further boost exports from the United States into Central America (9, 12, 28-29, 30). The American Farm Bureau Federation estimates the value of agricultural exports will increase by $\$ 1.5$ billion annually until 2024 (the year the agreement will be fully implemented). They note that the degree of increase will be high, given the fact that "preferential treatment allows the United States to take markets away from other competitors" (12: 8). It is predicted that these imports will have lower prices than foods produced in Central America, and are thus likely to lower farm gate ${ }^{5}$ prices $(9,28-29)$. Financial institutions also predict the agreement will boost U.S. direct investment in Central America and attract U.S.-based TFCs (28). It thus seems likely that CAFTA-DR will have an overall effect on food trade and investment and, therefore, food availability and prices.

\section{Impacts of CAFTA-DR on specific foods}

A detailed examination of the tariff schedules and supporting documents relevant to the food industry show that CAFTA-DR will specifically affect four categories of foods:

- Foods subject to tariff reductions in the short term (i.e., immediately or over 5 years) (categories A and B in Table 3);

\footnotetext{
5 Price of the product at the farm (excluding transport or delivery charges).
}

- Foods subject to increasing TRQs (i.e., the amount of imports permitted tariff-free);

- Foods currently subject to high tariffs (over 20\%); and

- Foods likely to be affected by a more commerce-friendly business environment and targeted by FDI.

The number of food products for which tariffs will be completely removed either immediately or over 5 years ranges from 489 in Honduras to 623 in Costa Rica (11) - more than half of current U.S. farm/food exports (15). As shown in Appendix 1, categories A and $\mathrm{B}$ primarily comprise different types of meat, meat parts, and processed meats; fish; vegetables; fruits and nuts; soybeans; processed savory products; snack foods; confectionery; and inputs to processed foods. Prior to CAFTA-DR, most tariffs for these food categories ranged from $5-15 \%$, although some were as low as zero and as high as $151 \%$.

Under CAFTA-DR, most foods subject to an increase in TRQs (i.e., the amount of imports permitted tarifffree) fall under the "sensitive product" category (Table 2). These products include pork; chicken leg quarters; a range of dairy products; rice (rough and milled); and corn (yellow and 
white); fresh and frozen potatoes and onions (in Costa Rica); and sorghum (in El Salvador). Over the long-term (5-18 years), incentives to export these foods into Central America will increase, along with the corresponding TRQs, which will eventually become unlimited (i.e., there will be no import tariffs for these products). Over the short term (up to 5 years), imports are only likely to increase if the current levels are less than the TRQs (i.e., if the quota will allow for expansion of the amount imported tariff-free). Appendix 2 shows the amount imported in 2005 was, in most cases, ${ }^{6}$ less than the short-term TRQs, suggesting the increased quotas will increase imports in the short term. This scenario is even more likely considering the fact that many of the foods were previously subject to very high tariffs.

Examples of foods with high pre-CAFTA-DR tariffs (over 20\%) are listed in Appendix 3.7 They include foods that will be affected by CAFTADR in both the short term (categories $\mathrm{A}$ and $\mathrm{B}$ ) and the longer term (categories $\mathrm{C}-\mathrm{Q}$ ) due to tariff reductions, and increasing TRQs.

Taking account of all the changes to tariffs and TRQs (Appendices 1-3), the foods most affected by the agreement are: poultry meat, processed meats, dairy products, some other processed foods, and some ingredients for processed foods.

Foods most likely to be affected by foreign investment incentives are highly processed foods (Table 4) manufactured, sold, and served by U.S.-based TFCs. Facing saturated markets at home, food manufacturing companies (e.g., those listed in Table 5) and supermarkets are increasingly seeking new growth in foreign countries (31-33). The data thus suggest that two broad food categories associated with the nutrition

\footnotetext{
6 Exceptions are rice and white/yellow corn for entry into all countries except two; chicken leg quarters for entry into Guatemala; pork and two dairy products for entry into Honduras; one dairy product for entry into El Salvador; and fresh onions for entry into Costa Rica.

7 Declining tariffs on the remaining foods-those with pre-CAFTA-DR tariffs lower than $20 \%$ that will experience decreasing tariffs over periods of more than 5 years-will have a less distinct effect, but are still cumulatively significant.
}

TABLE 4. The two food categories particularly affected by Central America-Dominican Republic-Free Trade Agreement (CAFTA-DR)

\begin{tabular}{ll}
\hline \multicolumn{1}{c}{ Category } & \multicolumn{1}{c}{ Specific foods } \\
\hline Meat (and animal feed) & Poultry (especially chicken leg quarters) \\
& Pork \\
& "Prime" and "choice" beef cuts \\
& Soybean meal \\
& Yellow corn \\
Highly processed foods & Processed meats (e.g., sausages, ham, bacon) \\
& Processed dairy (e.g., cheese, ice cream, yogurt) \\
& Prepared savory foods (e.g., french fries, soups, breakfast cereals, \\
& peanut butter) \\
& Snacks (e.g., potato chips, popcorn, chocolate sandwich cookies, filled \\
& chocolate bars) \\
& Ingredients for highly processed foods (e.g., mechanically deboned \\
& meats, skins and fats, hydrolyzed vegetable protein, dehydrated potato) \\
\hline
\end{tabular}

Sources: Derived from Appendices 1-3.

TABLE 5. Examples of trade associations and transnational food companies in favor of Central America-Dominican Republic-Free Trade Agreement (CAFTA-DR)

\begin{tabular}{ll}
\hline \multicolumn{1}{c}{$\begin{array}{c}\text { Trade groups representing } \\
\text { agribusiness and food processors }\end{array}$} & Transnational food companies \\
\hline Altria Group, Inc. (Philip Morris) & The Coca-Cola Company \\
American Feed Industry Association & ConAgra Foods \\
American Meat Institute & Dean Foods Company \\
American Frozen Food Institute & Dreyer's Grand Ice Cream, Inc. \\
American Soybean Association & General Mills, Inc. \\
Grocery Manufacturers of America & H.J. Heinz Company \\
International Dairy Foods Association & The Hershey Company \\
National Chicken Council (USA) & Kellogg Company \\
National Confectioners Association (USA) & Kraft Foods Inc. \\
National Grain and Feed Association (USA) & Mars, Incorporated \\
National Pork Producers Council (USA) & Nestlé USA, Inc \\
National Potato Council (USA) & PepsiCo, Inc. \\
U.S. Dairy Export Council & The Procter \& Gamble Company \\
USA Poultry and Egg Export Council & Sara Lee Corporation \\
& The J.M. Smucker Company \\
& Unilever United States \\
& William Wrigley Junior Company \\
\hline
\end{tabular}

Sources: $(45,61)$.

transition are likely to be particularly affected by CAFTA-DR: meat (and animal feed) and highly processed foods, including meat and dairy products (Table 4). These two food groups are discussed in more detail below.

\section{Implications of CAFTA-DR for meat}

CAFTA-DR will make it easier for U.S. agribusiness and agricultural producers to export meat and animal feed produced in abundance and at low cost in the United States. This includes pork, poultry, soybean meal and yellow corn, and the more expensive "prime" and "choice" beef cuts. Along with lower tariffs and higher TRQs, Central American countries' recognition of the U.S. meat inspection system as a result of CAFTA-DR is likely to facilitate trade and reduce potential food safety-related trade disputes. As shown in Table 5, the American meat industry, including the American Meat Institute, the National Pork Producers Council, the National Chicken 
Council, and the American Soybean Association, was strongly in favor of CAFTA-DR.

Pork and chicken are produced at very low cost in the United States due to the use of highly "efficient" Confined Animal Feeding Operations (commonly termed "factory farms"). These low-priced meats, mainly sold as cheap cuts, will compete directly with domestically produced pork and chicken, likely leading to lower domestic prices in the Central American signatory countries (11). For pork, the effects will probably be immediate, because the TRQs exceed current imports in all countries except Honduras, increasing over the long term as the quotas expand (Appendix 2). The U.S. pork industry estimates that pork exports to Central America will grow by 20,000 tons per year as a result of CAFTA-DR (34). The U.S. National Pork Producers Council attributes increasing pork exports to the effect of free trade agreements: according to their estimates, U.S. exports of pork and pork products have increased by more than $337 \%$ in volume terms and more than $292 \%$ in value terms since the implementation of NAFTA in 1994 and the Uruguay Round Agreement in 1995 (34).

Trade will also be facilitated for U.S. poultry products, for which many tariff reductions are immediate and/or previous tariffs were very high (Appendices $1-3)$, particularly chicken leg quarters. The U.S. poultry industry is constantly seeking new foreign markets for chicken leg quarters, a largely unwanted by-product of the white meat favored by U.S. consumers and the U.S. food industry (for use in processed products and fast foods) $(35,36)$. Produced at very low cost, these products are exported from the United States at the world's most competitive prices (37). Under CAFTADR, exports of chicken leg quarters are likely to increase in the short term due to the expanded TRQs, especially given the very high tariffs for these products prior to the agreement (Appendix 3). Because the TRQs for this product are quite small and will be phased out slowly, the effect will be even more significant in the long term, when their complete elimination is predicted to have a major impact on availability and price (11). The expanded market will include consumers purchasing inexpensive cuts in "wet markets" (meat and fish markets) as well as fast-food outlets (fried chicken restaurant chains, etc.).

By boosting exports of pork and chicken, CAFTA-DR is expected to increase demand for animal feed, such as soybean meal and corn, in the United States (38), while the expected increase in U.S. exports of these low-cost products is likely to lower Central American meat prices. As demonstrated in Colombia, imports of animal feed arising from trade liberalization with the United States can lower prices and promote consumption (39). Yellow corn and soybean meal are produced very cheaply in the United States, in part because of agricultural subsidies. Over the long term, Central American imports of yellow corn from the United States are likely to increase, because the corresponding TRQs are large; this increase in imports will lower domestic feed prices (11). In addition, soybean meal will be subject to lower tariffs in the short term (Appendix 1), enabling U.S. suppliers to out-compete other exporters and continue to provide low-cost feed to Central America for domestically produced meat. Before CAFTA-DR, Central America received $14 \%$ of all U.S. soybean meal exports, and in 2003, 95\% of soybean products in the region came from the United States (40).

In addition to its effect on low-value U.S. meat products, CAFTA-DR is also expected to influence imports of highvalue U.S. beef products ("prime" and "choice" cuts). These products are higher priced than Central American beef and differ from domestically available cuts in terms of consistency and flavor (grain-fed versus grass-fed meat respectively). Therefore, unlike pork or chicken, U.S. exports of highvalue beef product are unlikely to compete directly with beef produced domestically or by other major exporters such as Nicaragua and Honduras (41). They are, however, expected to appeal to higher-income Central American consumers who purchase beef at supermarket chains (a small percentage of the total population) as well as upscale hotels and restaurants in the region (42). As noted by USDA analysts, in Nicaragua "there is a potential niche for marketing to increase consumption of U.S. imported beef within the high-income segment of Nicaraguan society" (43: 2).

\section{Implications of CAFTA-DR for processed foods}

CAFTA-DR will increase the incentives and reduce the disincentives for U.S.-based TFCs to export processed foods (and their ingredients) to Central America. This is a result of lower tariffs overall, higher TRQs for processed dairy products, and greater business confidence in the region-a critically important factor in encouraging FDI. CAFTA-DR had strong support from the U.S. processed foods industry, which views Central America as a target area for growth in sales of processed foods (both exports and foods produced by local affiliates) (44) and has lobbied heavily in support of the agreement (Table 5). In 2005, 52 industry leaders submitted a letter in support of CAFTA-DR to the U.S. Congress, stating that "CAFTA offers significant benefits to the food and consumer products industry, and should be ratified as quickly as possible ..." (45). Signatories to the letter included companies involved in confectionery, snacks, breakfast cereals, ice cream, and deli meats, such as PepsiCo, Nestlé USA, Mars, and Kraft.

The Grocery Manufacturers Association (GMA), the leading processed foods industry trade group in the United States, commissioned a study to assess post-CAFTA-DR opportunities for increasing imports and sales of U.S. processed foods in Central America (44). A selection of the results, obtained using a food demand model, are shown in Table 6. Overall, imports of processed foods are predicted to increase from US\$359 million pre-CAFTA-DR to US\$662 million 
TABLE 6. Potential effect of Central America-Dominican Republic-Free Trade Agreement (CAFTA-DR) on imports of U.S. processed food into Central American signatory countries ${ }^{\mathrm{a}}$

\begin{tabular}{|c|c|c|c|c|c|}
\hline \multirow[b]{2}{*}{ Category } & \multicolumn{2}{|c|}{$\begin{array}{l}\text { Estimated } \\
\text { increase } \\
\text { In value }\end{array}$} & \multicolumn{2}{|c|}{$\begin{array}{l}\text { Estimated } \\
\text { increase } \\
\text { in quantity }\end{array}$} & \multirow[t]{2}{*}{$\begin{array}{c}\text { U.S. imports as } \\
\text { percentage of imports } \\
\text { from all countries into } \\
\text { Central America } \\
\text { by quantity } \\
\text { (post-CAFTA-DR) } \\
(\%)\end{array}$} \\
\hline & In US\$ & $\%$ increase & In million kg & $\%$ increase & \\
\hline Snacks ${ }^{b}$ & $14.7-32.1$ & 118 & $8.3-15.9$ & 92 & 26 \\
\hline Breakfast cereal & $6.5-17.6$ & 172 & $4.1-11.1$ & 170 & 29 \\
\hline Sauces $^{c}$ & $15.3-36.2$ & 137 & $11.0-26.4$ & 140 & 40 \\
\hline Soups & $17.3-29.9$ & 73 & $10-17.7$ & 76 & 62 \\
\hline Confectionery ${ }^{d}$ & $14-32.4$ & 132 & $5.9-14.4$ & 145 & 26 \\
\hline Cheese $^{\mathrm{e}}$ & $6.7-24.0$ & 264 & $2.7-9.4$ & 251 & 36 \\
\hline Sausages & $3.75-11.0$ & 192 & $1.8-5.2$ & 189 & 51 \\
\hline Processed deli meats ${ }^{\dagger}$ & 6-9 & 53 & $2.4-3.4$ & 46 & 80 \\
\hline \multicolumn{6}{|c|}{$\begin{array}{l}\text { Source: (45). } \\
\text { a Costa Rica, El Salvador, Guatemala, Honduras, and Nic } \\
\text { b Potato chips, crackers, sweet biscuits, popcorn, etc. } \\
\text { c Ketchup, mayonnaise. } \\
\text { d Chocolate, sugar confectionery. } \\
\text { e Cream cheese, mozzarella, processed cheese. } \\
\text { f Preserved cold cuts, meal sets such as "lunchables." }\end{array}$} \\
\hline
\end{tabular}

upon elimination of all tariffs (an $84 \%$ increase over current imports).

For example, snack foods exports represent an area of potential growth for U.S. suppliers under CAFTA-DR. Before the agreement, cookies exported from the United States faced import tariffs of $15 \%$, placing them at a disadvantage to products imported from elsewhere in Latin America and the European Union. Under CAFTADR, tariffs on chocolate sandwich cookies will be eliminated immediately; ${ }^{8}$ other cookies will have immediate tariff reduction (Appendix 1) and eventual tariff removal within 5 to 15 years. Tariffs on potato chips will also be removed over the short term. This product has particularly strong growth potential in Costa Rica, given the very high pre-CAFTA-DR tariff (41\%; Appendix 3). Popcorn will have its current tariff of 5-20\% eliminated over the short term, and Guatemala will eliminate tariffs on sweet pastries, corn chips, frozen pizzas, and baked crackers over a period of 5 years. Chocolate products and chewing gum

\footnotetext{
In a U.S. Senate committee hearing on CAFTA-DR, a Kraft Foods Inc. representative noted that tariffs on Oreo cookies-a type of chocolate sandwich cookie extremely popular in the United Stateswould benefit from immediate tariff-free status (50).
}

will become tariff-free after 5 years in Guatemala and Nicaragua; in other countries, the phaseout will be more gradual. Sugar confectionery will become tariff-free after 5 years in Guatemala and over a 15 -year period in other countries.

As a result of all these changes, the GMA predicts a $118 \%$ increase in value and a $92 \%$ increase in quantity of U.S. snack foods imports into Central America (Table 6). Frozen french fries are another example of this trend: the current tariff of $15 \%$ (except in Costa Rica, where it is $41 \%$ ) will be immediately removed (except in Costa Rica, where the TRQ will be removed in 5 years) (Appendices 1 and 3). U.S. exports of processed meats are also expected to increase. For example, sausages and processed deli meats (e.g., ham and bacon) have not been major export products thus far, but were previously subject to high tariffs in some countries (Appendix 3). After CAFTA-DR, they are expected to represent a majority of the import market in Central America $51 \%$ and $80 \%$ respectively) (44). Another area of expected growth is U.S. exports of processed cheese, which Kraft Foods estimates will be their greatest benefit from CAFTA-DR. Although current tariffs on processed cheese are high in three countries (Costa Rica, Nicaragua, and El Salvador), the TRQ increase under CAFTA-DR will allow immediate tariff-free access. This is likely to boost imports, as current levels are lower than the short-term quotas in all countries except Honduras (Appendix 2).

Processed food ingredients, such as hydrolyzed vegetable protein, mechanically deboned meat, and dehydrated potatoes, represent another potentially important area of growth for U.S. exports (Appendix 1). These products are in demand from processed food manufacturers seeking lower-priced ingredients.

For U.S.-based TFCs, the improved business and investment climate arising from CAFTA-DR may prove even more advantageous than lower tariffs. According to the GMA: "As important as the market access provisions of the CAFTA are to GMA companies, the real, long-term benefits of the [agreement] will come from the adoption of new rules that will lead to a stronger, more predictable business climate in the region" (46). Enhanced IPR and investor protections are cited as particularly important to increasing sales of branded products. Integration of the 
market under CAFTA-DR is also predicted to facilitate sales by creating economies of scale for production and distribution within the region. Thus, the agreement is likely to promote further investment from U.S.-based TFCs already active in the region, such as Frito-Lay, Kellogg's, Kraft, and Procter \& Gamble. It is also likely to encourage mergers and acquisitions between these companies and leading Central American processed food companies (e.g., the Diana Company in El Salvador, and Central de Alimentos in Guatemala, producer of the wellknown Señorial brand). The precedent has already been set in Mexico, where a significant consequence of the more liberal investment rules implemented in NAFTA was a rapid acceleration of FDI from the United States in Mexican food processing $(5,8)$. Between 1987 and 1997, U.S. FDI into the Mexican food-processing industry increased from US\$210 million to US\$5 billion (47). By 2003, affiliates of U.S.-based TFCs were selling $\$ 6.1$ billion worth of processed food in Mexico (48).

The potential impact of CAFTA-DR on the retail prices of processed foods is somewhat more complex. Many U.S. processed food brands-whether imported or produced by affiliates of U.S.-based TFCs-are relatively highpriced items only affordable by upperand middle-income consumers (49). U.S.-based TFCs have the advantage of a receptive market among these populations, many of whom perceive U.S. food products as higher quality than local brands (32). At the same time, many imported foods remain out of reach of the mass-market, which has limited purchasing power (income disparity in Central America remains high). Industry analysis suggests that out of 11.8 million Guatemalans and 6.2 million Hondurans, just 2.3 million and 2.9 million, respectively, can afford imported foods (32).

CAFTA-DR is likely to increase access to U.S. brands, however, as lower tariffs allow for more competitive pricing of U.S. products versus processed foods produced by domestic companies and other exporters. According to Kraft Foods, because tariff reduction under CAFTA-DR means lower prices for consumers, the "elimination of tariffs would boost sales and could encourage the production of new product lines" (50: 3).

\section{DISCUSSION}

\section{Implications of CAFTA-DR for the nutrition transition in Central America}

This study found that trade liberalization under CAFTA-DR is likely to affect the availability and prices of two food groups associated with the nutrition transition: meat and processed foods. This raises two questions: (i) Will this affect actual consumption of these products? and, if so, (ii) Will the associated public health concerns of obesity and diet-related chronic diseases be affected? With regard to the first question, as set out in the hypotheses below, there are several reasons to believe consumption will be affected. It should be noted, however, that the relationship between increasing availability of lower-priced foods from the United States and consumption is not necessarily straightforward; imported foods may simply replace other foods from domestic sources or competing exporters and therefore have no net effect on consumption.

Hypothesis 1: CAFTA-DR will lead to increased consumption of meat due to the increasing availability and lower prices of chicken and pork. CAFTADR will enable greater imports of cheaper chicken and pork cuts into the region. It will also boost domestic meat production, due to the availability of cheaper feed. As a result, net availability will increase and prices will decline. The increasing availability of chicken and pork at lower prices will then stimulate greater consumption. This hypothesis is supported by evidence from the United States, Mexico, and other Latin American countries, where chicken consumption has risen significantly as a result of increasingly intensive production systems, increased imports of lower-priced animal feed, and lower retail prices $(40,48,51,36)$.

Hypothesis 2: CAFTA-DR will lead to increased consumption of highly processed foods due to new competitive forces in the processed foods market. CAFTA-DR will make it easier for U.S.-based TFCs to export and do business in the region and thus promote increased imports of highly processed foods into Central America from the United States, and increased production by U.S. affiliates based in the region. This will increase availability and lower the prices of processed foods produced by U.S.-based TFCs and their affiliates. It is possible that this will simply lead to brand-switching-away from local and other imported brands to U.S. brands-rather than increased consumption of processed food overall. On the other hand, it could lead to higher overall consumption of processed foods due to the competitive forces created by the growing activity of U.S.-based TFCs (i.e., the increased competition could spur greater activity by Central American companies, create a more dynamic market for new products, stimulate more advertising, and place downward pressure on prices, resulting in greater availability of products, more competitive prices, and increased consumption) (5). The importance of advertising and other promotional activities in this process should not be underestimated. In a larger, more dynamic marketplace, advertising and marketing are used to attract attention to new products, create perceived differences between similar products, and increase the perceived value and desirability of products, thus encouraging more consumers to consume the products, and more producers to produce them. Strong investment in branding by U.S.-based TFCs differentiates U.S. products from domestic products, creating a perception of value of specific brands and categories that transcends the intrinsic value of the food items.

Hypothesis 3: CAFTA-DR will lead to the development of new consumption 
patterns due to the introduction of new, non-traditional foods. CAFTADR is likely to stimulate development and greater availability of meat and processed food products that are not "traditional" in Central America. These foods add to, rather than replace, foods from existing sources by virtue of the fact that they are "new" foods not produced locally. For example, domestically produced cheese is widely produced and consumed, but processed cheese products (e.g., Kraft Cheese Singles) are not. The same applies to "prime" cuts of beef and many types of processed meats and prepared savory foods. Although these products will most likely not pose direct competition for locally produced foods, they are expected to meet and create demand for new consumption patterns centered on "convenience."

Will these potential changes in food consumption patterns affect health? Tracing the linkages between economic changes, diet, and obesity is difficult because of the multitude of factors involved. It is clear, however, that increased consumption of meat and processed foods is a classic indicator of the nutrition transition, which, in turn, is linked to rising obesity and diet-related chronic diseases. This linkage may stem from changes in the foods consumed, or changes in the way they are consumed (e.g., an increase in snacking overall or an increase in the consumption of chicken in high-fat dishes from fast-food outlets). On the other hand, increased trade and investment may change food availability and prices in a positive way by increasing dietary quality.

Potential changes in food consumption and eating habits raises another important question: How will different socioeconomic groups be affected? As pointed out, U.S. brands of "prime" and "choice" meat and processed foods, including "diet" or "light" versions (for which demand in Central American countries is growing) are often targeted toward upper- and middle-income consumers. Yet the penetration and advertising of U.S. products make the product category (e.g., snacks) desirable among all groups, encouraging con- sumption of cheaper, non-U.S. products by those unable to afford the more expensive brands. In addition, as noted above, the lower tariffs, new competitive forces, and availability of lowerpriced ingredients will place downward pressure on prices of products produced by both U.S. and domestic companies, thus facilitating consumption by all. The nutrition transition can thus spread beyond middle- and upperincome groups to all sectors of society. A major concern is that, over the long term, less health-conscious groups of lower socioeconomic status will experience more of the ill-health effects of dietary changes, as seen in the United States. Evidence from Costa Rica suggests groups of lower socioeconomic status are less likely to consume healthier products (52). On the other hand, there is also the potential for under-consuming groups to gain greater access to micronutrient-rich products, such as meat, at more affordable prices.

\section{Limitations}

It should be noted that more analysis is needed to verify the hypotheses presented above, due to various limitations of the study. The first limitation is its focus on how consumption may be influenced by changes in trade, because trade is a two-way street. Just as trade influences food consumption habits, food consumption habits influence trade. In other words, as incomes and demand for "convenience" rises, demand increases for products from the United States and its companies, which then stimulates trade. In other words, changes in trade can be a result of demand, rather than a cause of it. This analysis does not estimate how important CAFTA-DR is relative to such changes in demand in driving the nutrition transition, or, for that matter, any other factor driving the nutrition transition. In addition, it does not measure the extent of the direct effects of increased imports or the indirect spillover effects on domestic food processing or meat production. Finally, the study does not analyze the potential effects of CAFTA-DR on domestic agricultural production of foods in Central America, which could result in additional spillover effects on food availability and prices.

\section{Conclusions}

The analysis presented in this article suggests CAFTA-DR will further the nutrition transition in Central America through its direct effects on food imports and investments from the United States, and through indirect, spillover effects on domestic meat production and the level of dynamism of the local food processing industry. Due to the limitations of the study, it cannot be asserted that CAFTA-DR will be ultimately responsible for greater consumption of meats and processed foods. However, it can be asserted that CAFTA is likely to facilitate dietary shifts, and increase the rate of change, where other conditions are favorable, in both supply and demand. If CAFTA-DR had never been signed, the nutrition transition would likely have continued in Central America. The effect of CAFTA-DR will be to accelerate the process and influence the shape and form of the dietary shifts.

\section{Recommendations}

In highlighting the potential effects of a free trade agreement on food consumption in a region of the developing world, this study raises important questions about health. There is a growing awareness among public health experts of the importance of trade in regard to public health (5356). In 2006, the WHO World Health Assembly adopted a resolution on International Trade and Health (WHA 59.26) that mandates WHO support of national governments in their efforts to frame coherent policies on trade and health and to build capacity in this area (57). These efforts should consider trade agreements' potential effect on dietary health in addition to their more widely known implications for access to drugs and health services and migration of health personnel. 
Within this context, it is recommended that national governments, international institutions, and non-governmental organizations pay greater attention to the potential effects of trade liberalization on dietary change. Three steps are needed. First, as done in this study, governments should analyze the potential effects of trade agreements on both food supply and food consumption (both positive and negative) to determine if the changes fostered by trade liberalization are coherent with national policies on diet and nutrition. WHO is currently develop- ing a diagnostic tool on trade and health that could help governments and other core stakeholders carry out this task. Second, if this process identifies policy incoherence (e.g., a rise in imports and foreign investment is increasing the consumption of trans-fatty acids, a food ingredient that has been targeted for reduction by current health ministry policies), decisionmakers should determine if mitigating efforts are required, taking into account the various nutritional, economic, and political contributing factors. Third, if the problem warrants action, stakeholders should strive to create greater coherence through effective policy development.

Acknowledgments. This study was

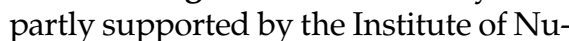
trition of Central America and Panama (INCAP) (Guatemala City, Guatemala), a specialized center of the Pan American Health Organization (PAHO). The authors would also like to thank Abby Hollister for her excellent editing of the manuscript, and the reviewers for their insightful comments.

\section{APPENDIX 1. Examples of foods in categories ${ }^{a} A$ and $B$ subject to short-term effects under Central America-Dominican Republic-Free Trade Agreement tariff reductions}

\begin{tabular}{|c|c|c|}
\hline Food & Categorya & Specific foods $\left(H^{b}{ }^{b} \text { codes }\right)^{c}$ and country ${ }^{d}$ \\
\hline Beef & B & Beef offal $(020621,020622,020629)$ in $\mathrm{ES}, \mathrm{H}$, and $\mathrm{N}$ \\
\hline \multirow[t]{2}{*}{ Processed meats } & A & $\begin{array}{l}\text { Prepared meals from ducks/geese/guinea fowl (16023900); Prepared turkey meat (16023100); Homogenized meat from } \\
\text { poultry (16021020) for CR }\end{array}$ \\
\hline & B & Homogenized meat from poultry (16021020) for ES, G, H, and N \\
\hline \multirow[t]{2}{*}{$\begin{array}{l}\text { Processed savory } \\
\text { products }\end{array}$} & A & $\begin{array}{l}\text { Rice-based breakfast cereals (190410) (i.e., foods obtained by the swelling or roasting of cereals or cereal products) in CR, } \\
\text { H, and N (already tariff-free in other countries); Soups and broths for CR and H (210410); Couscous and tapioca (1902, } \\
\text { 1903); Frozen french fries (2004.10) (except for CR, which has tariff-rate quota); Peanut butter (20081110) in CR, ES, G, } \\
\text { and H; Pastry cook preparations (flour mixes) (19019090) }\end{array}$ \\
\hline & B & Soups and broths for ES, G, and H $(210410 \ldots)$ \\
\hline Snack foods & A & $\begin{array}{l}\text { Potato chips (2005.20) for N; Popcorn (1005901000) for ES and G; Chocolate sandwich cookies (19053110) (other sweet } \\
\text { cookies [19053190] are in category C for ES, G, H, and N, and in category N for CR); Mixtures of fruits and nuts } \\
(20089200) \text { in all countries }\end{array}$ \\
\hline Confectionery & B & $\begin{array}{l}\text { Filled chocolate in slabs, blocks, or bars (18063100); Unfilled chocolate in slabs, blocks, or bars (18063200); Other } \\
\text { chocolate confectionery (18069000) for G, N; Chewing gum (17041000) for G and N; Sugar confectionery (17049000) in G }\end{array}$ \\
\hline \multirow[t]{2}{*}{$\begin{array}{l}\text { Inputs to processed } \\
\text { foods }\end{array}$} & A & $\begin{array}{l}\text { Processed potatoes, including potato flour (110510), dehydrated granules (11052010), dehydrated pellets }(11052020) \text {; } \\
\text { Protein concentrates ( } 21061000) \text {; Hydrolyzed vegetable protein }(21069010) \text {; Meat parts such as mechanically deboned } \\
\text { chicken and turkey, fresh or refrigerated }(02071310,02071410,02072610,02072710,02072690,02072790) \text {; beef offal in } \\
\text { CR (020621, 020622, 020629); Pig skin and offal in CR, ES, N }(02063,02064)\end{array}$ \\
\hline & $\mathrm{B}$ & Some meat parts, such as fatty livers of duck and goose (02073400) \\
\hline Processed drinks & A & Frozen orange juice (20091100) \\
\hline \multirow[t]{2}{*}{ Vegetables } & A & $\begin{array}{l}\text { All fresh vegetables for G; some vegetables for } \mathrm{CR}, \mathrm{ES}, \mathrm{H}, \mathrm{N}(\mathrm{e} . \mathrm{g} . \text {, witloof chicory [070521] and artichoke [070910]) in ES, } \\
\mathrm{G}, \mathrm{H}, \mathrm{N} \text {; mushrooms, fresh }(070951,52 \ldots, 59 \ldots) \text { \& dried }(071231,32 \ldots, 33 \ldots, 39 \ldots) \text {; Some processed } \\
\text { vegetables (tomato paste }[20029010] \text { ) }\end{array}$ \\
\hline & B & $\begin{array}{l}\text { Some vegetables for CR, ES, H, N (e.g., onion [070420]); Brussels sprouts [070420], dried \& powdered onion [071220]) in } \\
\text { ES, G, H, N; Globe artichoke \& sweet corn (070990) }\end{array}$ \\
\hline
\end{tabular}

Source: Annex 3.3. Tariff Schedules of Costa Rica, El Salvador, Guatemala, Honduras, and Nicaragua (13).

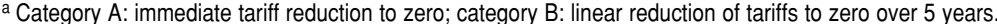

${ }^{b}$ International Harmonized Commodity Coding and Classification System.

' Descriptors of products specific to 2-, 4-, 6-, 8-, or 10-digit levels; in some cases truncated codes are given, depending on the product (i.e., some food categories are very general, allowing

for the use of one common 3-digit precursor [e.g., "030 ..."], whereas other categories are highly specific and are thus identifiable only through the use of the complete code).

d Unless otherwise specified, applies to all Central American signatories (Costa Rica, CR; El Salvador, ES; Guatemala, G; Honduras, H; and Nicaragua, N). 


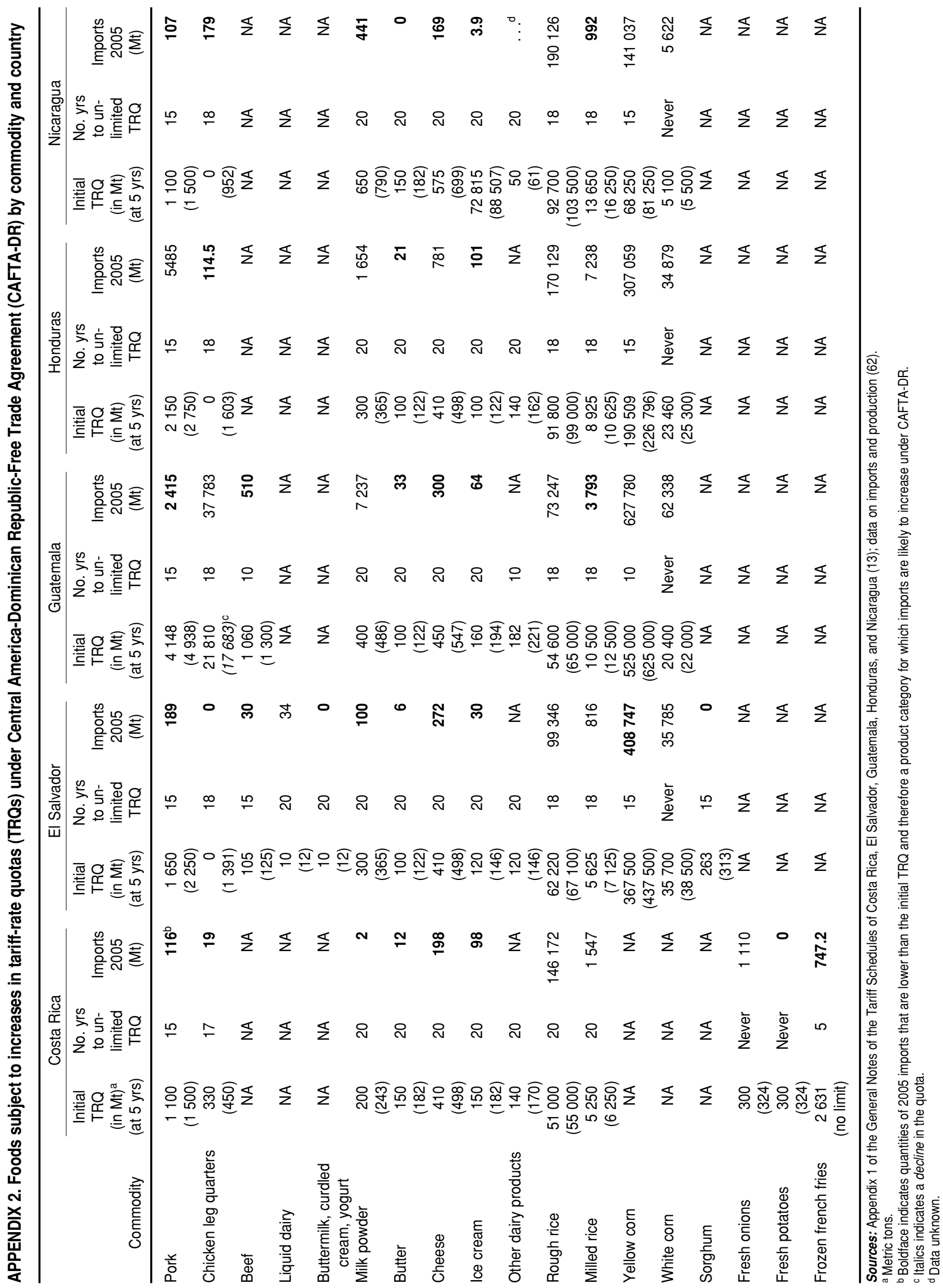




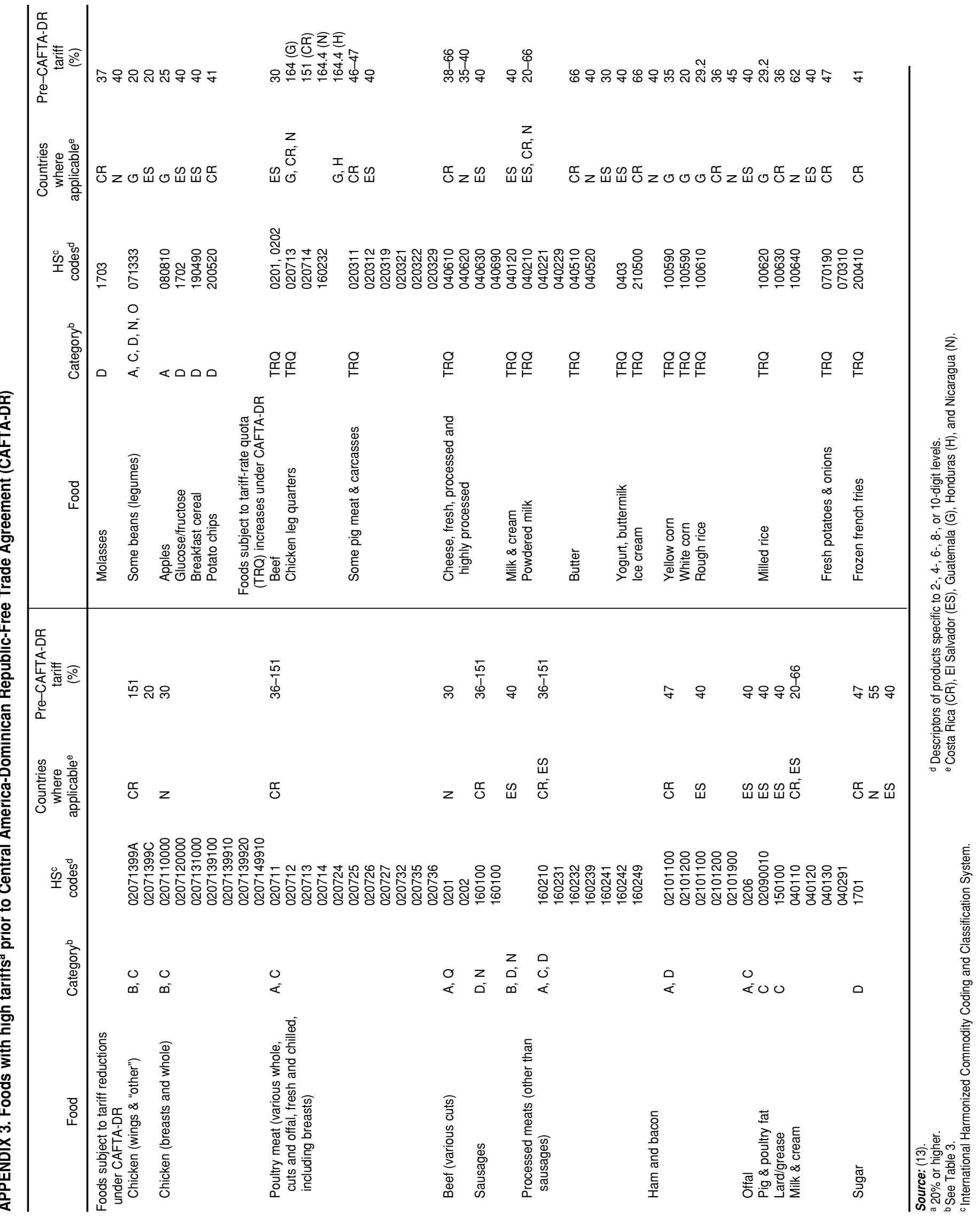




\section{REFERENCES}

1. Popkin BM. The nutrition transition and its health implications in lower income countries. Public Health Nutr. 1998;1(1):5-21.

2. FAOSTAT [database on the Internet]. Rome: Food and Agriculture Organization; c2007 [cited 2007 May 15]. Available from: http:// faostat.fao.org/site/368/default.aspx.

3. Stein AD, Gregory CO, Hoddinott J, Martorell $\mathrm{R}$, Ramakrishnan U, Ramírez-Zea M. Physical activity level, dietary habits, and alcohol and tobacco use among young Guatemalan adults. Food Nutr Bull. 2005;26(2 Suppl 1): S78-87.

4. Popkin BM. Technology, transport, globalization and the nutrition transition food policy. Food Pol. 2006;31(6):554-69.

5. Hawkes C. Uneven dietary development: linking the policies and processes of globalization with the nutrition transition, obesity and diet-related chronic diseases. Global Health [serial on the Internet]. 2006; [cited 2006 August 29]:2(1):[about 25 p.]. Available from: http://www.globalizationandhealth. com/content $/ 2 / 1 / 4$.

6. Rayner G, Hawkes C, Lang T, Bello W. Trade liberalization and the diet transition: a public health response. Health Promot Int. 2006;21 Suppl 1:67-74.

7. Pingali P. Westernization of Asian diets and the transformation of food systems: implications for research and policy. Food Pol. 2007; 32(3):281-98

8. Hawkes $\mathrm{C}$. The role of foreign direct investment in the nutrition transition. Public Health Nutr. 2005;8(4):357-65.

9. World Bank. DR-CAFTA: challenges and opportunities for Central America. Washington: World Bank, Central America Department and Office of the Chief Economist Latin America and Caribbean Region; 2005. Available from: http://siteresources. worldbank. org / LACEXT / Resources / 258553 1119648763980/DR_CAFTA_Challenges_ Opport_Final_en.pdf.

10. Office of the United States Trade Representative. United States and Central America sign historic free trade agreement [news release]. 28 May 2004. Washington: USTR; 2004 [cited 2007 May 15]. Available from: http://www.ustr.gov/Document_Library/ Press_Releases/2004/May/United_States_ Central_America_Sign_Historic_Free_Trade Agreement.html.

11. Morley S. Trade liberalization under CAFTA: an analysis of the agreement with special reference to agriculture and smallholders in Central America. Washington: International Food Policy Research Institute; 2006. DSGD Discussion Paper No. 33/MTID Discussion Paper No. 95.

12. American Farm Bureau Federation. A vote for DR-CAFTA is a vote for agriculture. Washington: AFBF; 2005.

13. Office of the United States Trade Representative. CAFTA-DR Final Text. Annex 3.3-Tariff Schedules of Costa Rica, El Salvador, Guatemala, Honduras, and Nicaragua, and Appendix 1 of the General Notes of the Tariff Schedules. [document on the Internet]. Wash- ington: USTR; 2004 [cited 2007 April 26]. Available from: http://www.ustr.gov/Trade Agreements / Regional/CAFTA/CAFTADR Final Texts/Section Index.html.

14. Office of the United States Trade Representative. Sanitary and phyto-sanitary measures. In: CAFTA-DR Final Text [document on the Internet]. Washington: USTR; 2005 [cited 2007 April 26]. Available from: http://www.ustr. gov/Trade_Agreements/Regional/CAFTA/ CAFTA-DR Final Texts/Section Index.html.

15. Office of the United States Trade Representative. CAFTA fact sheet. Free trade with Central America [document on the Internet]. Washington: USTR; 2003 [cited 2007 April 9]. Available from: http://www.ustr.gov/Document Library/Fact Sheets/2003/Free Trade with Central_America_Summary_of_the_USCentral_America_Free_Trade_Agreement.html.

16. U.S. Department of State. 2005 Investment Climate Statement-Honduras [document on the Internet]. Washington: DOS, Bureau of Economic and Business Affairs; 2005 [cited 2007 March 19]. Available from: http://www. state.gov/e/eeb/ifd/2005/43030.htm

17. U.S. Department of State. 2005 Investment Climate Statement-El Salvador [document on the Internet]. Washington: DOS, Bureau of Economic and Business Affairs; 2005 [cited 2007 March 19]. Available from: http://www. state.gov/e/eeb/ifd/2005/43026.htm.

18. U.S. Department of State. 2006 Investment Climate Statement-Guatemala [document on the Internet]. Washington: DOS, Bureau of Economic and Business Affairs; 2006 [cited 2007 March 19]. Available from: http:/ /www. state.gov/e/eeb/ifd/2006/61984.htm.

19. U.S. Department of State. 2007 Investment Climate Statement-Costa Rica [document on the Internet]. Washington: DOS; 2007 [cited 2007 March 19]. Available from: http:/ /www. state.gov/e/eeb/ifd/2007/80691.htm.

20. United Nations Conference on Trade and Development. Foreign Direct Investment (FDI) Profile: Nicaragua [document on the Internet]. Geneva: UNCTAD; 2004 [cited 2007 March 20]. Available from: http://www.unc tad.org/sections/dite_fdistat/docs/wid_cp_ ni_en.pdf.

21. Office of the United States Trade Representative. Statement of why the Dominican Republic-Central America-United States Free Trade Agreement is in the interests of U.S. commerce [document on the Internet]. Washington: USTR; 2004 [cited 2007 March 21]. Available from: www.ustr.gov/assets/Trade Agreements/Bilateral/CAFTA/Transmittal/ asset_upload_file959_7817.pdf.

22. American Federation of Labor and Congress of Industrial Organizations. USTR misleads Congress on CAFTA labor provisions [news release]. Washington: AFL-CIO; 2004 [cited 2007 March 26]. Available from: http:/ /www. citizen.org/documents/CAFTAandLabor Issues(AFL-CIO).pdf.

23. Center for International Environmental Law; Defenders of Wildlife; Earthjustice; Friends of the Earth; League of Conservation Voters; National Environmental Trust; et al. [Letter to
Congress opposing the Central American Free Trade Agreement (CAFTA)] [document on the Internet]. (Feb. 18, 2004) [cited 2006 March 26]. Available from: http://www. citizen.org/documents/EnviroCAFTACong Letter.pdf.

24. Center for Policy Analysis on Trade and Health. CPATH briefing paper on the USDominican Republic-Central American Free Trade Agreement (DR-CAFTA) [document on the Internet]. San Francisco: CPATH; 2004 [cited 2008 October 10]. Available from: www.cpath.org/sitebuildercontent/site builderfiles/caftabriefingpaper1april2004.pdf.

25. Office of the United States Trade Representative. Understanding regarding certain public health measures. In: CAFTA-DR Final Text [document on the Internet]. Washington: USTR; 2004 [cited 2007 April 26]. Available from: http://www.ustr.gov/Trade Agreements/Regional/CAFTA/CAFTA-DR_ Final_Texts/Section_Index.html.

26. Office of the United States Trade Representative. Labor. In: CAFTA-DR Final Text [document on the Internet]. Washington: USTR; 2005 [cited 2007 April 26]. Available from: http://www.ustr.gov/Trade_Agreements/ Regional/CAFTA/CAFTA-DR_Final_Texts/ Section Index.html.

27. Office of the United States Trade Representative. Environment. In: CAFTA-DR Final Text [document on the Internet]. Washington: USTR; 2005 [cited 2007 April 26]. Available from: http://www.ustr.gov/Trade Agreements / Regional/CAFTA/CAFTADR Final Texts/Section_Index.html.

28. Rodlauer M, Schipke A. Central America: global integration and regional cooperation. Washington: International Monetary Fund; 2005. Occasional Paper No. 243. Available from: http://www.imf.org/external/pubs/ $\mathrm{ft} / \mathrm{op} / 243 /$ index.htm.

29. Todd J, Winters P, Arias D. CAFTA and the rural economies of Central America: a conceptual framework for policy and program recommendations. Washington: Inter-American Development Bank; 2004. IADB Report No. RE2-04-016.

30. U.S. Department of Agriculture, Foreign Agricultural Service [homepage on the Internet]. Washington: USDA, FAS; c2008 [cited 2008 April 18]. Dominican Republic-Central America-United States Free Trade Agreement (CAFTA-DR); [about 2 screens]. Available from: http://www.fas.usda.gov/itp/CAFTA/ cafta.asp.

31. Regmi A, Gehlhar M. New directions in global food markets. Washington: U.S. Department of Agriculture; 2005. Agriculture Information Bulletin No. 794. Available from: http:// www.ers.usda.gov/Publications/aib794/.

32. Herrera M, Orellana D, Suazo H. Three Central American markets add up to opportunities for U.S. food exporters. AgExporter. 2001; 13(9):18-20. Available from: www.fas.usda. gov/info/agexporter/2001/sept/page18-2. pdf.

33. Reardon T, Berdegué JA. The rapid rise of supermarkets in Latin America: challenges and 
opportunities for development. Dev Policy Rev. 2002;20(4):371-88.

34. National Pork Producers Council. NPPC and state pork producer associations write Congress encouraging support of CAFTA-DR [news release]. 17 Mar 2005. Washington: NPPC; 2005 [cited 2007 April 11]. Available from: http://www.nppc.org/wm/show. php? $\mathrm{id}=427 \& \mathrm{c}=1$.

35. Dyck J, Nelson K. World meat trade shaped by regional preferences \& reduced barriers. Agricultural Outlook [serial on the Internet]. 2000 March: [about 4 p.]. Available from: http://www.ers.usda.gov/publications/ag outlook/mar2000/ao269d.pdf.

36. Haley MM. Changing consumer demand for meat: the U.S. example, 1970-2000. In: Regmi A, editor. Changing structure of global food consumption and trade. Washington: U.S. Department of Agriculture; 2001. p. 41-8. Agriculture and Trade Report WRS011. Available from: http://www.ers.usda.gov/Publications/ WRS011/.

37. U.S. Department of Agriculture. United States-Central America-Dominican Republic Free Trade Agreement: commodity fact sheet [document on the Internet]. Washington: USDA; 2005 [cited 2007 May 12]. Available from: http://www.fas.usda.gov/info/fact sheets/CAFTA/poultry.pdf.

38. American Soybean Association. ASA urges ratification of Central America Free Trade Agreement [news release]. 11 Apr 2005. St. Louis (MO): ASA; 2005 [cited 2007 April 11]. Available from: http://www.soygrowers. $\mathrm{com} /$ newsroom/releases/2005\%20releases / r041105.htm.

39. Hawkes C. Agricultural and food policy for cardiovascular health in Latin America. Prev Control. 2006;2(3)137-47. Available from: http://linkinghub.elsevier.com/retrieve/ pii/S1573208807000074.

40. American Soybean Association. CAFTA: the right market at the right time [document on the Internet]. St. Louis (MO) and Washington: ASA and National Oilseed Processors Association; 2007 [cited 2007 April 11]. Available from: http://www.soygrowers.com/international/ CAFTA\%20.pdf.

41. U.S. Department of Agriculture, Foreign Agricultural Service. Costa Rica livestock and products annual report 2005 [document on the Internet]. Washington: USDA, FAS; 2005 [cited 2007 April 12]. Global Agriculture Information Network (GAIN) Report No. CS5014. Available from: http://www.fas. usda.gov/gainfiles/200508/146130637.pdf.

42. U.S. Department of Agriculture, Foreign Agricultural Service. El Salvador livestock and products annual report 2001 [document on the Internet]. Washington: USDA, FAS; 2001 [cited 2007 April 12]. Global Agriculture Information Network (GAIN) Report No. ES1006. Available from: http://www.fas. usda.gov/gainfiles/200108/125681794.pdf.
43. U.S. Department of Agriculture, Foreign Agricultural Service. Nicaragua livestock and products annual report 2003 [document on the Internet]. Washington: USDA, FAS; 2005 [cited 2007 April 12]. Global Agriculture Information Network (GAIN) Report No. NU3004. Available from: http://www.fas. usda.gov/gainfiles/200308/145985784.pdf.

44. International Trade Services Corporation. GMA's processed food demand model: assessing the potential value of the Central American FTA on U.S. exports of branded food and beverage products. Washington: ITSC; 2004.

45. Grocery Manufacturers of America. CAFTADR endorsed by leaders of 52 food, beverage and CPG companies [news release]. 10 May 2005 [cited 2007 April 11]. Washington: GMA 2005. Available from: http://www.gmabrands. $\mathrm{com} /$ news $/$ docs $/$ NewsRelease.cfm?DocID= 1505.

46. U.S. Free Trade Agreement with Central America and the Dominican Republic: Hearing Before the International Trade Commission: testimony of Sarah Thorn, senior director, International Trade, Grocery Manufacturers Association. (April 27, 2004). Available from: http: / / www.gmabrands.com/news / docs/Testimony.cfm?DocID=1334.

47. Bolling C, Elizalde JC, Handy C. U.S. firms invest in Mexico's processed food industry. Food Review. 1999;22(2):26-30.

48. Zahniser S. NAFTA at 13: implementation nears completion. Washington: U.S. Department of Agriculture, Economic Research Service; 2007. Agricultural Outlook Report No. WRS0701. Available from: http://www.ers. usda.gov/publications/wrs0701/.

49. Orellana D, Vasquez E, Huete S. Guatemala retail food sector. Annual 2004. Washington: U.S. Department of Agriculture, Foreign Agricultural Service; 2004. Global Agriculture Information Network (GAIN) Report No. GT4018.

50. U.S.-Central America-Dominican Republic Free Trade Agreement: Hearing Before the Comm. on Finance: testimony of Mark Berlind, executive vice president, Global Corporate Affairs, Kraft Foods, Inc. [document on the Internet]. (April 13, 2005) [cited 2007 April 12]. Available from: http://www.senate.gov/ $\sim$ finance/hearings/testimony/2005test/ mbtest041205.pdf.

51. Zahniser S, Link J, editors. Effects of North American Free Trade Agreement on agriculture and the rural economy. Washington: U.S. Department of Agriculture, Economic Research Service; 2002. Agricultural and Trade Report No. WRS021. Available from: http:// www.ers.usda.gov/Publications/WRS0201/.

52. Colón-Ramos U, Kabagambe EK, Baylin A, Ascherio A, Campos H, Peterson KE. Socioeconomic status and health awareness are associated with choice of cooking oil in Costa Rica. Public Health Nutr. 2007;10(11):1214-22.
53. Blouin C. Trade policy and health: from conflicting interests to policy coherence. Bull World Health Organ. 2007;85(3):169-73.

54. Labonte R, Sanger M. Glossary on the World Trade Organisation and public health: part 2. J Epidemiol Community Health. 2006;60(9): 738-44.

55. Shaffer ER, Waitzkin H, Brenner J, JassoAguilar R. Global trade and public health. Am J Public Health. 2005;95(1):23-34.

56. Labonte R, Sanger M. Glossary of the World Trade Organisation and public health: part 1. J Epidemiol Community Health. 2006;60(8): 655-61.

57. World Health Organization, Fifty-ninth World Health Assembly. Resolutions and decisions. WHA59.26-International trade and health [document on the Internet]. Geneva: WHO; 2006 [cited 2007 May 11]. Available from: http://www.who.int/gb/ebwha/pdf files/WHA59/A59_R26-en.pdf.

58. U.S. Department of Agriculture, Economic Research Service. A glossary of trade terms. Agricultural Outlook [serial on the Internet] 1996 Dec: [about 2 p.]. Available from: www. ers.usda.gov/publications/AgOutlook/Dec 1996/Ao236c3.pdf.

59. World Trade Organization. Glossary [document on the Internet]. Geneva: WTO; 2007 [cited 2007 March 19]. Available from: http:/ / www.wto.org/english/thewto_e/glossary_ e/glossary_e.htm.

60. Office of the United States Trade Representative. National treatment and market access for goods. In: CAFTA-DR Final Text [document on the Internet]. Washington: USTR; 2004 [cited 2007 April 26]. Available from: http://www.ustr.gov/Trade_Agreements/ Bilateral/CAFTA/CAFTA-DR_Final_Texts/ Section Index.html.

61. Altria Group, Inc.; American Bakers Association; American Farm Bureau Federation; American Feed Industry Association; American Frozen Food Institute; American Meat Institute; et al. [Letter from food and agricultural organizations to The Honorable J. Dennis Hastert] [document on the Internet]. (Feb 1, 2005) [cited 2006 April 12]. Available from: http://www.corn.org/Hastert.doc.

62. Foreign Agricultural Service U.S. Trade Internet System [database on the Internet]. Washington: U.S. Department of Agriculture, FAS; 2007 [cited 2007 April 26]. Available from: http://www.fas.usda.gov/ustrade/.

Manuscript received on 15 May 2007. Revised version accepted for publication on 2 June 2008. 
RESUMEN Objetivos. Identificar el posible impacto del Tratado de Libre Comercio entre Centroamérica y República Dominicana (TLCCA-RD) sobre el patrón de consumo de alimentos relacionados con la transición alimentaria, la obesidad y las enfermedades crónicas asociadas con la alimentación.

\section{Implicaciones del Tratado de Libre Comercio entre Centroamérica y República Dominicana sobre la transición alimentaria en Centroamérica}

Palabras clave
Métodos. Se examinó el TLCCA-RD para identificar las medidas que podrían afectar a la disponibilidad de alimentos y los precios al consumidor.

Resultados. El TLCCA-RD contiene acuerdos sobre tarifas, cuotas arancelarias y regulaciones sanitarias y fitosanitarias con implicaciones directas sobre la disponibilidad y los precios de varios alimentos. Los acuerdos sobre inversión, servicios y derechos de propiedad intelectual son también importantes debido a que crean un ambiente de negocios más favorable a inversiones a largo plazo de empresas transnacionales de la industria alimentaria. La liberalización del comercio por el TLCCARD podría incrementar la disponibilidad y reducir los precios relativos de dos grupos de alimentos asociados con la transición alimentaria: las carnes y los alimentos procesados. Esto podría ser resultado directo del aumento en las importaciones desde los Estados Unidos de América y de la producción de las compañías estadounidenses basadas en Centroamérica, y resultado indirecto del aumento en la producción local de carne (por la mayor disponibilidad de alimentos más baratos para animales) y el aumento en la producción de alimentos procesados por compañías locales (debido a un ambiente comercial más competitivo).

Conclusiones. El TLCCA-RD podría reforzar la transición alimentaria en Centroamérica al elevar el consumo de carne, alimentos muy procesados y alimentos nuevos no tradicionales. La comunidad de salud pública debe estar más atenta a las implicaciones de los acuerdos comerciales sobre la salud alimentaria. Los Gobiernos y las entidades relacionadas con el tema deben evaluar la coherencia entre los cambios propiciados por los acuerdos comerciales específicos y las políticas alimentarias y dietéticas nacionales.

Desarrollo económico, obesidad, enfermedad crónica, trastornos nutricionales, economía, República Dominicana, Centroamérica.

\section{Nutrition and an Active Life: From Knowledge to Action}

Nutrition and an Active Life: From Knowledge to Action is an anthology by leading public health experts from PAHO and the international development community. The book's selections focus on how research in nutrition and the promotion of active lifestyles can provide vital input for the creation of public policy and planning and for the design, implementation, monitoring, and evaluation of programs.

This publication is an important contribution that should be of particular interest to practitioners, researchers, and decision-makers in the fields of health promotion, community education, nutrition, maternal and child health, physical activity, policy development in public health and urban planning, and other related areas.

To order this publication: http://publications.paho.org; Fax: (301) 206-9789; E-mail: paho@pmds.com; PAHO/WHO office in your country

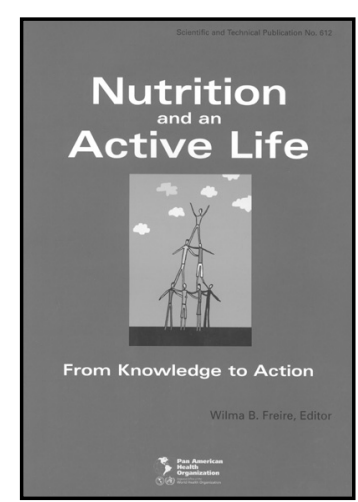

2005, pp., 260

ISBN: 9275116121

US\$ 20.00 in Latin America

and the Caribbean/

US $\$ 30.00$ elsewhere

Order code: SP 612 